\title{
Editorial
}

\section{Social Justice at the Crossroads}

\author{
WENDY HARCOURT
}

Volume 45 of development is devoted to deepening collective discussions on the impact of globalization in our lives. It takes up many of the themes already discussed in past volumes of the journal, inviting us to explore further the questions those earlier editions raised. The first issue continues the discussion on place-based politics, the second records civil society's responses to globalization, especially in the wake of the tragic events in the US on September 11th, the third reviews the last decade of institutional attempts to put in place 'sustainable development' and the last takes a look at the impact of the Internet on political and economic development.

The overall aim of the volume is to deepen the debates, reflection and knowledge on how civil society, international organizations, progressives and peaceloving people have been building new economic, cultural and social global processes. The volume will explore the social and cultural changes that people around the world face with economic globalization. The focus is on the new types of cultural and social relations being formed by the more participatory and responsible engagement by diverse actors. As Ricardo Petrella stated in 1995: 'Fortunately, globalization does not stop at the globalization of capital' (Harcourt, 2001).

This first issue of volume 45 is inspired by the earlier issue "Globalism and the Politics of Place' and the work of the historian Arif Dirlik and feminist geographer Doreen Massey, among others. It is one of the activities of the project 'Power, Culture and Justice: Women and the Politics of Place', co-ordinated by the Society for International Development with the support of the Rockefeller Foundation. The journal will be translated into Spanish and will be launched at the Centre for Critical Theory and Transnational Studies at the University of Oregon in the USA. The team members of the research project (Fatma Alloo, Marisa Belausteguigoitia, Arif Dirlik, Arturo Escobar, Julia Graham, Wendy 
Harcourt, Smitu Kothari, Khawar Mumtaz and Dianne Rochealeu) have provided the background framework to the journal's focus on how 'women's place-based politics' is effecting social change particularly through networking - creating and providing new ways of thinking about culture, identity and rights in today's globalized world.

The journal aims to capture what is new in globalization for women's experience of place, taking 'place' as a potentially transformative site of political practice. The articles conceptualize globalization in ways that disrupt the notion of a binary relationship between 'the local' and 'the global' in order to clarify the historical continuities and discontinuities of today's experience of globalization. It looks at how diverse groups of women, often marginalized or invisible in mainstream politics, are engaged in new forms of politics centred around the body, home, environment and community. In gathering together these stories the journal documents how women are actively shaping and confronting globalization. Their stories chart out the lines of escape and the strategies women (in communities and as individuals) are creating to transform their 'place'.

In the opening article Arturo Escobar joins me in introducing the core theme of the issue - women and the politics of place - and explains the conceptual framework underlying the articles that follow.
The Upfront section features responses from leading intellectuals to the ideas explored in the article as the basis of the project 'Power, Culture and Justice: Women and the Politics of Place'. In the thematic section the team members of the project elaborate further on the framework, exploring body politics networking, environmental organizing and indigenous politics. The local/global section highlights women's 'place' in social movements and grassroots organizations, women and economic activism in place and women's individual and collective experiences of displacement. SID On-line looks at women's networking around place, supplemented by a detailed 'Window on the World' with descriptions of the myriad of women's place-based political groups around the world. Some of the most recent feminist literature is reviewed in the 'Book Review' and 'Book Shelf'.

Putting together the journal has been an inspiring and joyous collective effort - even in a historic moment of great doubt and uncertainty - achieved with the enthusiastic and necessary support of the editorial assistants for this volume, Michal Osterweil and Lila Rabinovich. I trust that the readers of 'Place, Politics and Justice: Women Negotiating Globalization' will be inspired by some of the vision and hope that the project is generating.

\section{Reference}

Harcourt, W. (January-April 2001) ‘Civil Society Responds’, Politica Internazionale XXIX Nos 1-2.

development is abstracted in Cab Abstracts, Communication Abstracts, Environmental Abstracts, GEOBASE, Geo Abstracts: Human Geography, HRI Reporter, International Development Abstracts, International Labour Documentation, International Political Science Abstracts, Social Services Abstracts, Sociofile and Sociological Abstracts; and is indexed in CSA Political Science \& Government, Econlit, Environmental Abstracts, International Bibliography of the Social Sciences, Journal of Economic Literature, OCLC Public Affairs Information Service. 